\title{
THE DISCURSIVE CONSTRUCTION OF INDIGENOUS BELIEF ISSUE IN THE JAKARTA POST
}

\author{
Suprayogi Suprayogi, Dian Puspita, Sandi Nuansa, Kamelia Sari \\ Universitas Teknokrat, Bandarlampung, Indonesia \\ E-mail: dian.puspita@teknokrat.ac.id
}

Received: 2021-11-02

Accepted: 2021-11-29

\begin{abstract}
As indigenous belief acknowledgement in Indonesia is still progressive, debatable but limitedly investigated from critical discourse analysis perspective, this research is aimed at revealing the discursive construction of indigenous belief issue in The Jakarta Post. This research focuses on analyzing indigenous belief as phenomenon, indigenous believers and government as social actor through the analysis of nomination and predication strategies. Articles published in The Jakarta Post online newspaper from 2013 - 2020 are chosen as corpus data. To analyze this research, Discourse-Historical Approach by Wodak and Meyer (2009) is used as the framework. This research also employs corpus analysis using Sketch Engine. The finding suggests that the issue centralized in the discussion of identity card and human right framed in five different periods. The use of collective proper name, anthroponym and deixis are significant to refer to indigenous believers, meanwhile institutional name, anthroponym and synecdoche are mostly used as referent for government. There is a shift of predication strategies from negative to positive when it discussed government policy on putting indigenous belief column on identity card. This research suggests that the use of corpus software as well as manual corpus screening is important to locate more detail language data.
\end{abstract}

Keywords: corpus linguistics, discourse-historical approach, discursive construction, indigenous belief.

\section{Introduction}

Creating inclusive society becomes important agenda of many countries including Indonesia. It is a type of society where people embrace tolerance, accept any kinds of diversity, and hear other people's voice (Kapur and Ghose, 2020). The idea of inclusive society is not merely about acceptance of disability, age, sex, origin, but also about religious practices that people uphold. One of the dynamic religious issues that is widely concerned in Indonesia is the existence of indigenous belief. Indigenous belief refers to the practice of believing in nature and spiritual power, then people create meaning-making on it. Tafjord (2013) defines indigenous religion as the religions that have originated among or are considered original to groups of people who are regarded as indigenous people. Furthermore, indigenous belief term is coined and collocated as opposed to major religions society upholds.

In Indonesian context, Indigenous believers have constitutional right protection (Sumarto, 2017) or guaranteed by the state; however, in the practical level, they are 
The Discursive Construction of Indigenous Belief Issue in The Jakarta Post, Suprayogi Suprayogi, Dian Puspita, Sandi Nuansa, Kamelia Sari

currently striving for advocacy to gain acknowledgement and fighting against discrimination. To begin with, Indonesian government in New Order era only acknowledged Islam, Catholicism, Protestantism, Buddhism, Hinduism, and Confucianism. Indigenous believers conflict with government body, face difficulties to access health care and economic aid. Furthermore, they receive discriminatory acts in societies because they are seen as "outgroup" with 245 national organizations, 954 local organizations and almost one million followers (Budjanto, 2016).

The perception of society toward indigenous believers is highly determined by the discourses developed and reproduced around them, one of which is powered by mass media. Construction of meaning of discourse is based the context of mode, time, place, and people (Afrianto, 2017; Puspita \& Pranoto, 2021b) meaning that mass media is the active platforms where discourse is always produced and reproduced. Mass media, like other media, in the first level has the role to share information about what happened to the world today to public especially what people are not familiar with (Happer \& Philo, 2013). In the next level, McCombs \& Valenzuela (2007) agrees that media do have roles in shaping public opinion. Interestingly, media becomes the fourth pillar of states that become the partner for activist, political leader and policy maker to try to change the waves of society (Sharma, Sharma, \& Rawat, 2018). As consequence, media readers stand either in favor or opposite of certain issue, then will affect how they react to the issue.

One of the mass media intensively reported this issue in The Jakarta Post, an English newspaper from Indonesia. The Jakarta Post is the first Indonesian newspaper written in English firstly published in 1983 (Irianto, Sukarno, Joko, \& Mursid, 2018) and also becomes credible newspaper in Indonesia, and targets foreigner and educated Indonesian (Morissan, 2019). Furthermore, The Jakarta Post has more news coverage on this issue compared to other Indonesian English newspapers.

The focus of this research is to see how the issue of indigenous belief is discursively constructed in The Jakarta Post. The issue of indigenous belief has risen approximately for 41 years in Indonesia, and it has evolved to many directions. Thus, this issue cannot be seen synchronically, but diachronically. To uncover this, Discourse-Historical Approach (DHA) is employed.

\section{Literature Review}

The issue of indigenous belief advocacy cultivated by and presented in mass media is within the interest of linguistics and critical discourse analysis. Discourse analysis itself means analyzing the language beyond the sentence (Afrianto \& Restika, 2018) and critical means that context and justification should be taken into account. Because language conveys distinctive meaning and expression from the people we speak to (Anigbogu, 2015) the selection of linguistic devices in communication will determine how certain issue is portrayed. In addition, mass media have articulatory function where it raises issues that are rarely discussed and addressed (Sen, 2011) like indigenous belief.

The research on Critical Discourse Analysis on mass media with the context of Indonesian issues were extensively conducted in the past few years. (Utami \& Kurniawan (2017) investigated the representation of President Jokowi in The Jakarta Post using DHA focusing on nomination and predication strategies. Evayani \& Rido (2019) analyzed the representation of social violence in The Jakarta Post newspaper and The New York Times using the framework of Van Leuween's social actor representation. In addition, Utami (2018) studied how LGBT is represented in The Jakarta Post and Jakarta Globe using Fairclough's 
three-dimensional framework. However, the research on underrepresented issue in mass media like indigenous belief is very limited to discuss. Furthermore, analyzing this issue in The Jakarta Post is important as it becomes the mirror of Indonesia in international eyes.

DHA is one of the approaches under Critical Discourse Analysis (CDA) developed by Ruth Wodak from Vienna School of Discourse Analysis that take historical, social, and political context into account (Wodak, 2011). Furthermore, DHA has strong roots in linguistics, and it concerns with discourse and discrimination, discourse in the media, discourse and history, discourse and identity, discourse and politics, and discourse and ecology (Reisigl, 2012).

DHA consists of five strategies to reveal the representation. Those strategies are "nomination strategies, predication strategies, argumentation strategies, perspectivization strategies, and intensification strategies" (Wodak, 2015: 12). Two strategies becoming the focus of this study are nomination, and predication. Nomination strategies can be seen from linguistics device such as pronoun, deictic, membership categorization devices, proper name, rhetorical devices, anthroponyms used to refer to the actors and action (Wodak \& Meyer, 2001). Nomination strategies focuses on the use of linguistic referents to persons, things and events. Predication strategies are observed from the use of adjective, collocation, explicit predicate, etc (Wodak \& Meyer, 2001). Predication strategies are strategies of attributing positive or negative qualifications of persons, things and events. These strategies are to see how indigenous religion believers, governments and the issue of indigenous religion are attributed to.

\section{Research Method}

In line with the research objective which to investigate the discursive construction of indigenous knowledge issue, this research employed descriptive qualitative method. This method focuses on multiple perspective analysis, applies both inductive and deductive processes (Cresswell, 2009) concerns on verbal description of each data (Perry, 2005 in Kuswoyo \& Susardi, 2018; Ivana \& Suprayogi, 2020) and aims at understanding the construction of meaning made by people (Merriam \& Tisdel, 2016).

Data in this research were text related to indigenous belief taken from The Jakarta Post online newspaper's articles accessed in www.thejakartapost.com. The Jakarta Post was selected because of its credibility and extensive outreach and coverage of the indigenous religion issues. The articles published in the period of 2013 - 2021 with 33 articles containing 21,936-word token of specialized corpora. The eight years' span indicates the first news and the last news on indigenous religion in Indonesia published by The Jakarta Post website.

Data were collected through search engine of The Jakarta Post official website from page one until the the last page of the official website featuring the keyword for the article search is indigenous religion, indigenous belief and native faith. The articles used in this research were the articles discussing indigenous belief in Indonesian setting later called as Indonesian indigenous belief (IIF) corpus. The articles are compiled in notepad text format (.txt) to make it compatible for corpus software used in this research, that is Sketch Engine. By using Sketch Engine, the corpora can be uploaded in online database (Pranoto \& Yuwono, 2019) and enables the corpora to be grammatically tagged making it possible for analyzing the collocation online (Baker, Gabrielatos, \& McEnery, 2013). Furthermore, Sketch Engine is used to analyze corpus in in large data so that the findings are more reliable.

Several steps of analysis were arranged to answer the research question. The first is the analysis of word list or the most frequent word to see the dominant issue portrayed in the discourse. The second analysis is the analysis of representation of indigenous belief, 
The Discursive Construction of Indigenous Belief Issue in The Jakarta Post, Suprayogi Suprayogi, Dian Puspita, Sandi Nuansa, Kamelia Sari

indigenous believers, and government by analyzing the nomination and predication strategies employed. The analysis of intertextuality, interdiscursivity and the diachronic development of the issue are intertwined in the discussion of the strategies.

\section{Results and Discussion}

Wordlist or most frequent word is believed to reflect the main discussion in a corpus. In the context of CDA, wordlist is assumed to carry the most widely discussed topic in discourse. The following is the table showing the top five most frequent words in noun, verb and adjective part of speech in relation to Indonesian indigenous belief. These three parts of speech are considered significant in contributing the discursive construction of the issue.

\begin{tabular}{|c|c|c|c|c|c|}
\hline Noun & Frequency & Verb & Frequency & Adjective & Frequency \\
\hline Faith & 440 & Have & 380 & Native & 180 \\
\hline Religion & 437 & Say & 294 & Indigenous & 159 \\
\hline Follower & 257 & Recognize & 117 & Religious & 153 \\
\hline Card & 220 & Do & 93 & Indonesian & 71 \\
\hline Belief & 162 & Leave & 57 & local & 62 \\
\hline
\end{tabular}

Table 1. Most frequent words in Indonesian Indigenous Belief corpus

The discourse on indigenous belief that The Jakarta Post presented is always linked to the discussion on those 15 words. The noun faith, belief and religion strengthen the discourse that what matters in indigenous religion advocacy itself is the religion affair in the eyes of government and society. The word follower centralizes the discourse on the believer of the indigenous religion. Then, the word card appears since indigenous believers have struggled for obtaining identity card to the same rights as what other religions have since the New Order era in Indonesia. Among the five verb in the top list, verb recognize and leave signifies that the biggest struggle of indigenous believers is the recognition from the state itself where they should leave the religion column in their identity card in the past before having some policy changes in the following decade. The word native and indigenous are dominant adjective that collocate with the word belief or believer as the central issue. From these 15 words, it can be implied that The Jakarta Post centralize the discourse construction on ID card issue, recognition and its implication. Furthermore, the interpretation of these wordlist is the starting point to see the significant words surrounding the issue. Thus, they are elaborated in the analysis of nomination and predication in the following discussion.

\subsection{Nomination and predication strategies of indigenous belief}

In DHA, the main discourse topic is called as event, phenomena, and object. To begin with, in the corpus data, the term belief in the phrase indigenous belief is interchangeably used with term faith, and religion in most of context with the occurrence of 162 times, 440 times and 437 times respectively. It implies that The Jakarta Post refers to the same thing. According to Newman, belief, faith, and religion are different terms; however, they are often used interchangeably. Belief is the things that can make people believing in faith meanwhile faith is the things that can make people know and worship in certain religion, and religion is the action of the faith (Newman, 2004). The use of different names referring to one name shows that The Jakarta Post positions these three terms equally as the spotlight regardless their scope of acknowledgement.

The frequent adjective of native and indigenous modifies the word faith, belief and religion. There are 229 concordance lines for native and 163 concordance lines for 
indigenous. These two refer to the origin of a thing that in this context, native faith signifies the faith that is not brought from outside of a region, it is clearly from and born inside of the region. There is a concept of "native" versus "brought" religion. Islam, Christianity, Catholicism, Hinduism, Buddhism, and Confucianism were brought to Indonesia through migration in different periods. According to Krom (1950, in (Rani, 2010), Hinduism and Buddhism reached Indonesia in the first century brought by traders and Brahmins from India. Islam was brought by Muslim traders from Gujarat, Arabia and Persia in the 15th century AD (Sunarso, 2018) meanwhile Christianity and Catholicism were disseminated by the Portuguese then followed the Spanish spices traders who traded spices in 15th century AD (Haris, 2013) while Confucianism was originated from China and brought by Chinese immigrants as early as third century BC (Yang, 2005).

(1) Bonnie had to submit a letter from Majelis Luhur Kepercayaan Indonesia (MLKI), an organization which accommodates followers of local religions and indigenous beliefs throughout Indonesia, to the agency.

The adjective local as seen in example (1) is also used to modify faith appearing 61 times. The term local refers to small scale region. The Jakarta Post used in this term to show the small outreach and regional scope of indigenous faith because usually the term local collocate with term regional and national that are showing wider geographical area. For instance, there is an indigenous belief from North Sumatera Province worshipped by Batak tribes, Indonesia, called Malim with 5,000 followers called Parmalim centralizing in the province (Gultom, 2018).

The term minority faith used in the corpus to be the opposition of term majority religion which are the religion acknowledged by states. The word minority usually refers to minority groups. The theory of minority explains that minority groups get stressed from experiences of discrimination and stigma that come from society which affect to their mental health (McConnell, Janulis, Gregory, Truong, \& Michelle, 2019). These minority religious believers might have same treatment like other underprivileged society such as LGBT, disable community, race and ethnic minority. The Jakarta Post selects the term minority to make the society and reader connect the issue of other minority groups in Indonesia that often get negative perception and discrimanatory threat from society. The example (2) shows how minority faith follower is linked to the problem in building worship place.

(2) Even for those who subscribed to minority faiths recognized by the government, the bureaucracy could find ways to discriminate against these people, especially when they set out to build a place of worship.

The discourse about indigenous belief also involves the use of proper name, that is the specific name of indigenous belief itself. Some of the examples are Malesung, Sundanese Wiwitan, Javanese Kejawen, Padma Buwana, Javanese mysticism, Marapu and AKP, Aliran Kebatinan Perjalanan, Kaharingan, Agama Adam. These nomination strategies show that indigenous religions are very diverse in Indonesia in line with its ethnic diversity and further signify that indigenous belief is not an exclusive issue centralized in Java island as the area of capital city is located, rather it is a national issue where the beliefs have also existed in other parts of Indonesia such as in Sumatera island, Borneo island, Celebes Island, and Nusa Tenggara archipelago. 
The Discursive Construction of Indigenous Belief Issue in The Jakarta Post, Suprayogi Suprayogi, Dian Puspita, Sandi Nuansa, Kamelia Sari

\begin{tabular}{|l|l|}
\hline Label & Collocates \\
\hline ID Card & Special, different, hope, revise, obtain, seek, issue, create, change. \\
\hline Right & Equal, civil, political, fundamental, ignored, denied, freedom, protect, ensure. \\
\hline
\end{tabular}

Table 2. The collocation of ID card and right

The term ID card and right are important to highlight in this reasearch as they appear significantly in the corpus and collocate with verbs related to the indigenous believers' struggle in advocating their status. Table 2 shows specific collocates that have the tendency to portray the strugling process of indigenous belief advocacy. ID card collocate with adjective special and different indicates that the issue concern on differences of ID card that indigenous believers got compared to the ID card owned by people who uphold one of the acknowledged religion. The difference lies on how to fill religious column, in which in the beginning they have to choose one of the acknowledged religion. The term obtain, issue, and seek were to describe indigenous believers' difficulty to get ID card and other civil document like marriage administration document that they are considered not fulfilling religion requirement. The difficulty of issuing ID card is widely debated until the level of Constitutional Court of Indonesia, that is why in the discourse the term create, revise and change are significant. The discourse construction of ID card issue is consequently linked to the term right in the corpus signifying that equal right, right protection, right of freedom for indigenous believers. The Jakarta Post support the idea that Indigenous believers is positioned equally among other acknowledged religious believers. However, the right to obtain civil administration documents were denied and ignored. The historical milestone of indigenous belief advocacy is illustrated in the following table.

\begin{tabular}{|c|c|c|c|c|}
\hline New Order & 2006 & 2013 & 2017 & 2019 \\
\hline $\begin{array}{l}\text { Indigenous } \\
\text { believers were } \\
\text { forced to } \\
\text { choose one of } \\
\text { the state } \\
\text { religion to be } \\
\text { put in ID card. } \\
\text { The beievers } \\
\text { were accused of } \\
\text { being } \\
\text { communist and } \\
\text { atheist. }\end{array}$ & $\begin{array}{l}\text { Govt } \\
\text { Imposed } \\
2006 \\
\text { Population } \\
\text { Administratio } \\
\mathrm{n} \text { Law: } \\
\text { require the } \\
\text { religion } \\
\text { column in id } \\
\text { card is left } \\
\text { blank. }\end{array}$ & $\begin{array}{l}\text { Govt Imposed } \\
2013 \text { Civil } \\
\text { Administration } \\
\text { Law stating } \\
\text { that the } \\
\text { column of } \\
\text { religion should } \\
\text { be left blank. }\end{array}$ & $\begin{array}{l}\text { Constitutional } \\
\text { Court Rulled. } \\
\text { Indigeneous } \\
\text { belief is put in id } \\
\text { card column } \\
\text { (judicial review of } \\
\text { the } 2013 \text { Civil } \\
\text { Administration } \\
\text { Law) } \\
\text { MUI suggested } \\
\text { special ID card for } \\
\text { faith believers. }\end{array}$ & $\begin{array}{l}\text { Regional } \\
\text { administration } \\
\text { issued ID card with } \\
\text { faith field "Belief in } \\
\text { Almighty God". }\end{array}$ \\
\hline
\end{tabular}

Table 3. Timeline of indigenous belief advocacy

The process of obtaining current ID card with faith field "Belief in Almighty God" instead of religion field started from New Order Era 1967 - 1998 (President Soeaharto). This process is interwined with the discrimination, accusation, and rejection by the government as well as the society that live around them. The revision of the law has done by government for several times indicated responding debates among the followers. 


\subsection{Nomination and predication strategies of indigenous believer}

Reisigl and Wodak (2001) stated that there are certain political, social and psyhcological function in the process of how actors in the discourse are labelled. Thus, refering to the context of social actors in this issue, why certain naming is selected is important to discuss. To begin with, let's start from the main actor, that is indigenous believer. The term believers in indigenous believers is interchangeably used with other nouns such as followers, worshippers, and subscriber as seen in the example (3), (4), and (5). These terms share similar meaning that they are committed groups of people performing the religious practices in their daily activities. However, the term worshippers show that they are loyal and commited follower that do the practice of indigenous belief depicted in traditional way. In addition, the Indonesian term for indigenous believers that is penghayat kepercayaan is frequently mentioned in the article. The Jakarta Post introduce this term to international audience that this issue is exclusive in Indonesian context.

(3) But for a leader, not every decision should be motivated by political expediency, not when it involves the fate of millions of native faith subscribers who have fought against discrimination for decades.

(4) "Indonesia's indigenous faith followers have experienced fluctuating government recognition, as seen in Atas Nama Percaya (In the Name of Belief), a 2019 documentary film that premiered at a special screening in Jakarta on Nov. 30 to an audience comprising teachers, indigenous faith followers and the general public.

(5) All of the worshippers were barefoot and clad in traditional Batak attire. Women were dressed in kebaya with ulos cloth draped over their shoulders.

Another nomination strategy prominently found in this research is proper name. Proper name reffering to collective individual in organization such as Majelis Luhur Kepercayaan Indonesia (MLKI), Indigenous Peoples Alliance of the Archipelago (AMAN), Native Faiths Followers Organization (HPK) are mentioned. This is to show that the believers are affiliated, not standing alone, and they have community to pursue their advocacy. Furthermore, it also reflects the diversity of indigenous religion group. When the institutional names are used, it means that The Jakarta Post makes the case not brought personally but institutionally; therefore, it affects all the members in the institution. Some examples of anthroponym were mentioned also by The Jakarta Post such as Dewi Kanti, Rukka Sombolinggi, Nanang, Hadi Prajoko, and Bonnie. The use of personal anthroponym is to personalize the issue and to portray that certain issues does happen in everyday context. These anthroponyms usually appear together with the organization name as seen in the example (6).

(6) Today, Retno is one of the 254 indigenous faith instructors who have been assessed by the Majelis Luhur Kepercayaan Indonesia (MLKI), an organization that groups the followers of Indonesia's indigenous belief systems.

Deixis also plays quite significant roles in positioning the indigenous believers. The person deictic word of they, he, she, $I$ and we are extensively used and refer to various context as seen in the example (7), (8), and (9). They, she and he were used in the context of how government talks about the believers, showing exclusion of government party meanwhile the $I$ and we, that are more intensively used in the text, were employed by The Jakarta Post to exploit the vivid narrative and personalized phenomena experienced by the believers. 
The Discursive Construction of Indigenous Belief Issue in The Jakarta Post, Suprayogi Suprayogi, Dian Puspita, Sandi Nuansa, Kamelia Sari

(7) "This is only a matter of administration and the government is responsible for protecting all Indonesian citizens regardless of their adherence to a certain religion or native faith. The most important thing is they believe in God the Almighty," Tjahjo said

(8) Another Parmalim, Jonga Gultom, said that he and his family had been subject to alienation from his community before he registered as a Christian.

(9) "I feel that it is getting easier for us to work on administrative arrangements, specifically regarding the inclusion of local faiths on our identity cards, after the Constitutional Court's ruling," he told The Jakarta Post on Tuesday.

Indigenous believers were attributed with various qualities and features by The Jakarta Post. To see further how indigenous believers are predicated, the collocation analysis was conducted through Sketchengine by identifying words surrounding the label of believers and the beliefs.

\begin{tabular}{|l|l|}
\hline Label & Collocates \\
\hline Believers & Banned \\
\hline Followers & Survive, suffer, experience, blank \\
\hline Indigenous religion, native religion & Target, various, unrecognized \\
\hline Indigenous faith, native faith & $\begin{array}{l}\text { Countless, accused, adopt, exclude, grant, } \\
\text { allow, lump }\end{array}$ \\
\hline Indigenous belief, native belief & $\begin{array}{l}\text { Stigmatized, forced, religionized, replaced, } \\
\text { regarded }\end{array}$ \\
\hline
\end{tabular}

Table 4. Collocation of indigenous belief and indigenous believers

Collocates in Table 4 shows that indigenous believers are in general portrayed in negative ways. The term banned appear when one of them were banned to hold religious celebration, in this case is Seren Taun or annual paddy rice harvesting celebration. The various negative verbs employed by The Jakarta Post signifies that indigenous believers experienced multiple injustice and humiliation acts. The term accused was widely used in the context during New Order regime $(1967$ - 1988) when the believers were accused to be communist or atheist, a group that is opposed by the regime. The term suffer and experience associated with the context of struggle and difficulty in assessing public administration documents such a marriage lisence, family card and birth certificate, meanwhile the term recognized mostly appear in the discussion of only six religions were acknowledged by the state.

(10) Ex-members of Gafatar, which has been banned by the government, have been the victims of intolerant acts, including suffering the humiliation of being evicted from their homes in Kalimantan in January 2016

(11) Euis, who has been married since December 2014, faced numerous hurdles in processing her registration, ranging from prolonged bureaucracy matters to repeated rejections by authorities.

The predication strategies employed by The Jakarta Post to see the predicates attached to indigenous believers is analysed through manual screening document analysis in which each article is checked one by one. This is to see special linguistic features that could not be screened through Sketchengine. From this next layer analysis, it is found that there are noun, adjective and verbs that are arranged subsequently to create vivid imagery of the 
issue. The Jakarta Post employed the term pariah and second class citizen to depict how strong the treatment indigenous believers have got. The example (10) and (11) show that the suffering of indigenous believers occurred in many layers.

Seeing the milestone of indigenous believe advocacy from New Order until 2019, the predication of indigenous believers changes sightly. In the article covering indigenous believers's treatment in New Order era, the predicates are mostly negative indicated by repetitive words forced, choose, and communist. Negative attribute in this context refer to negative treatment received by the believers. In the period of 2006, 2013 and 2017, the negative attributes attached to the group as well in most of article coverage. In this period, the dominant diction used to describe them are discriminatory and difficult because the decision to leave the religion column blank can be interpreted that they don't have any religion thus called atheist meanwhile the term difficult is associated to the context of difficulty to build place of worship. However, in the article covering 2017 and 2019 policy regarding the faith column that is filled with "Belief in God the Almighty" showing both positive and negative predicate. The term celebrate and jubilant were intensively used to describe the positive feeling of the believers. The selection these words are selected to express the relief and excessive happiness after long struggle of advocacy they strive. However, the term difficult remains intensive in this time frame because although the new policy has been issued, these group still face difficulty in accessing administrative services.

\subsection{Nomination and predication strategies of government}

Government, as the main institution towards indigenous religion advocacy, is constructed through various linguistic devices in this newspaper. Institutional name is widely used in the news text referring to government as a body or institution. There are local government, The Culture and Education Ministry, The Religious Affairs Ministry, police, and house of representative. The use of local government shows how indigenous believers do not only interact with the central but also local government. Local governments, as the first access gate for indigenous believer to express their voice, usually await decisions from the central government because the policy making is in the level of central government. Furthermore, in this case, the inconsistent policy on indigenous religion result in the diverse interpretation in the level of local government. The referent The Culture and Education Ministry appears because Indigenous belief phenomena is positioned as a part of culture, so it is the responsibility of the Ministry of Education and Culture. In addition, the ministry has responsibility in formulating the curriculum for all schools in Indonesia including inclusive education that provide rooms for the believer's children to learn indigenous religion at school. Another ministry referent that is apparent in this research is The Religious Affairs Ministry. As the name suggest, the appearance of this referent is to show how the indigenous religion issue is under the affair of this ministry. The referent police reflect the condition that clashes between indigenous religion community and other groups were so serious that results in violence, and police takes a part in mediating both parties.

Nomination strategies referring to government is also seen from the use of anthroponym, where government is represented as individual. The word Jokowi dan Tjahjo Kumolo as synecdoche significantly appear in the text as seen in the example (12) and (13). Jokowi is Indonesian president in the period of $2014-2019$ and $2019-2024$. One of the Jokowi-Jusuf Kalla's government missions is to create a developed, balanced society and control based on the rule of law. The mission includes a system of law enforcement, protection of marginal groups and law enforcement and human rights (Radjab, 2018). Tjahjo 
The Discursive Construction of Indigenous Belief Issue in The Jakarta Post, Suprayogi Suprayogi, Dian Puspita, Sandi Nuansa, Kamelia Sari

Kumolo, on the other hand, is the Ministry of Home Affair Republic of Indonesia in the period of Joko Widodo Presidency. The ministry has the functions to regulate population and civil registration. In this case, this ministry has responsible to manage and provide the population administration service for all Indonesian citizens from the center to the region. The use of anthroponym as government actor shows that The Jakarta Post concerns on the vital figure that directly related to the issue of indigenous believers.

(12) "President Joko "Jokowi" Widodo's administration, which had earlier revised Law No. 23/2014 on local administrations to enable citizens to leave the religion column blank on identification and family cards"

(13) "Home Minister Tjahjo Kumolo has said the e-ID cards would be available to native faith followers after the 2018 regional elections in June"

The term state and Indonesia are also often used as form of synechdoce to refer to government. The term state refers to broader scope of organization that does not only involve government as the element but also population, sovereignty and territory (Marume, Jubenkanda, Namusi, \& Madziyire, 2016) meanwhile Indonesia refers to the country of Republic of Indonesia. The use of these term by The Jakarta Post signifies that the government is handling the bigger scope of territory and matters even more that intersect to many aspects such as politic, economy, social and education.

\begin{tabular}{|l|l|}
\hline Referent & Collocates \\
\hline Government & Repression, inaction, recognize, responsible, proactive, ban \\
\hline Police & Criticized, mobilized. \\
\hline State & Discrimination, interference, refuse, not recognize \\
\hline Indonesia & Adhere, recognize, try. \\
\hline
\end{tabular}

The referents of government are also attributed to various predicates. Tables 5 indicates the most frequent collocates appear in the corpus. From the table, it is shown that government tends to be mostly labelled with negative predication by The Jakarta Post with some positive labels also appear. The government treats indigenous believers by banning them in religious practices, refuse their existence to be acknowledge and discriminate them in accessing public and administrative services. In addition, some strong attributes are attached surround the government referent as stated in the following example.

(14) The government and the President have done very little to change the state of affairs. Twenty-eight of the 31 cases recorded by Imparsial this year were committed by local residents with the support of hard-line mass organizations.

(15) Although this decision is the best the government could do, it is wrong-headed on so many levels, adding yet another bureaucratic layer to the already complicated bureaucracy.

(16) The watchdog group said the country was paving the way for further discrimination against minority groups by preserving a number of problematic and draconian regulations.

(17) The call fell on deaf ears when lawmakers and the government pressed ahead with an amendment to the 2006 Civil Administration Law, which continued to impose a ban preventing adherents of non-recognized religions from putting their faiths on their ID cards. 
These four selected samples show that government is depicted as an institution that is not aware of the indigenous religion issue and has problematic regulation. These terms were use to give strong image that indigenous belief issue need to be known bu public, addressed as well as seriously taken into account by government. Furtehrmore, government is represented variously throughout the timeline of indigenous believe advocacy as seen in Table 3. In the time frame of New Order, term excessive control and authoritarian dominate the corpus. It is related to government stance in recognizing only five religions and forcing the society to choose one of them. In the time frame of 2006, the term discriminatory was dominant, indicating government policy on leaving the religion column of id card blank. Moving to the time frame of 2017 referent, Tjahjo Kumolo as Home Minister dominates the corpus with a many positive attributes such as coordinate, push, urge in the context of coordinating with Ministry of Religious Affair and push local government to serve indigenous believers without any discrimination, and to compile the indigenous believer data. This positive attribute shows government's seriousness to accommodate the voice of indigenous believers. In the time frame of 2019, government is represented as local administration that focuses on the issuance of ID card with "Belief in God The Almighty" column. In this context, The Jakarta Post position government as the insititution that directly interact and give the service to the indigenous believer community as seen in the following example.

(18) The Bandung City Population and Civil Registry Agency in West Java has for the first time issued identity cards (KTPs) with a column for faith rather than religion.

This positive representation in the time frame of 2019; however, is added with negative portrayal of government stating that the 2019 policy is only for native followers that becomes the member of particular organization, thus it is still considered that government is not fully accommodative yet. From this, it can be seen that each time frame will not focus on one side of representation.

\section{Conclusion}

This research examines the discursive construction of indigenous belief issue by analyzing the nomination and predication strategies employed by The Jakarta Post to indigenous belief object, indigenous believer and government. This research also considers historical development of the issue as it is one of the cores of Discourse-Historical Approach (DHA) assisted with Sketch Engine for corpus analysis.

Overal, the indigenous belief, indigenous believer, and government are referred and predicated variously. Nomination strategies of indigenous belief are seen from the use of various referent such as proper name of indigenous belief organization and alternative term of belief such as faith and religion. Indigenous belief is predicated with adjective to strengthen its representation as marginalized object like the use of minority, local and native. The indigenous belief issue is also centralized in the discussion of identity card and human right and divided into five different phases of advocacy namely new order, 2006, 2013, 2017, and 2019 period. Furthermore, indigenous believer is nominated through alternative terms (e.g. followers and worshippers), collective proper name referring to indigenous believers' organization, anthroponym and deixis. The use of the proper name of organization refers to voice of indigenous believers collectively as well as the existence indigenous belief that is already institutionalized. Anthroponym is used to highlight personalized experience of discrimination from the believers meanwhile deixis is employed to exclusion of indigenous believers towards government. Social actor of government is 
The Discursive Construction of Indigenous Belief Issue in The Jakarta Post, Suprayogi Suprayogi, Dian Puspita, Sandi Nuansa, Kamelia Sari

mostly indicated through institutional name, anthroponym and synecdoche. The use of institutional name indicates certain government institution directly involved and related to the indigenous belief advocacy. Anthroponym is employed to indicate which government individual are and should be handling this isse so that it can link to who has the responsibility to solve meanwhile synecdoche is used to refer the issue that has scope as big as the state or country.

The predication strategies employed by The Jakarta Post to indigenous believers and social actors reflect the same tendency. I the time frame of New Order era until 2017, negative attributes attached to government showing the discriminative policy and treatment meanwhile the negative attributes attached to indigenous believers showing the struggle and discriminatory act they received. The negative attributes gradually change in the time frame of 2019 in which government is considered accommodative towards the voice of indigenous believers, and the indigenous believers expresses their joy for the fulfilled advocacy, that is recognition of their belief in identity card.

This research concludes that The Jakarta Post has constructed the discourse of indigenous belief issue into the portrayal of indigenous believers' advocacy processes and at the same time the portrayal of government's response towards the issue. The research has further highlighted that indigenous believers side more than the government. It shows that the issue needs to be addressed through the factual information that The Jakarta Post has served to public. This further methodologically contributes that corpus linguistics using Sketch Engine did help the analysis in term of finding majorly discussed issues and general representation of social actors through the use of keyword, concordance and collocation features; however, in the context of analyzing using Discourse-Historical Approach (DHA), manual corpus screening is highly needed to see the time frame of an issue and to analyze the dominant nomination and representation of social actors within the certain time frame.

\section{References}

Afrianto, A. (2017). Grammatical Cohesion in Students' Writing: a Case At Universitas Teknokrat Indonesia. LEKSEMA: Jurnal Bahasa Dan Sastra, 2(2), 97. https://doi.org/10.22515/ljbs.v2i2.899

Afrianto, A., \& Restika, A. (2018). Fungsi Pemarkah Wacana: Sebuah Kasus di Kelas Berbicara pada Level Universitas. LITERA, 17(1), 70-89.

Anigbogu, N. C. (2015). Linguistic Devices in Media Discourse: A Case Study. International Journal of English Language and Linguistics Research, 3(5), 25-33.

Baker, P., Gabrielatos, C., \& McEnery, T. (2013). Sketching muslims: A corpus driven analysis of representations around the word "Muslim" in the British press 1998-2009. Applied Linguistics, 34(3), 255-278. https://doi.org/10.1093/applin/ams048

Budjanto, O. W. (2016). Penghormatan Hak Asasi Manusia bagi Penghayat Kepercayaan di Kota Bandung. Jurnal Balitbangkumham, 7(35-44).

Cresswell, J. (2009). Research Design: Qualitative, Quantitative, and Mixed-Methods Approaches (Third Edit). https://doi.org/10.1080/14675980902922143

Evayani, W., \& Rido, A. (2019). Representation of Social Actors in Sexual Violence Issue in The New York Times and The Jakarta Post Newspapers: A Critical Discourse Analysis. Teknosastik, 17(2), 43. https://doi.org/10.33365/ts.v17i2.322

Gultom, I. (2018). Malim Religion: A Local Religion in Indonesia. International Journal of Sociology and Anthropology Research, 4(2), 1-10.

Happer, C., \& Philo, G. (2013). The role of the media in the construction of public belief and 
social change. Journal of Social and Political Psychology, 1(1), 321-336. https://doi.org/10.5964/jspp.v1i1.96

Haris, A. M. (2013). Indonesian Religious Evolution: Applying Bellahan's Theory in Indonesian Context. The Sociology of Islam, 3(2).

Irianto, S., Sukarno, S., Joko, S., \& Mursid, -. (2018). The Ideology Stance of the Jakarta Post through Headlines on Negara Islam Indonesia's Case. 247(Iset), 496-498. https://doi.org/10.2991/iset-18.2018.100

Ivana, P. S. I., \& Suprayogi, S. (2020). THE REPRESENTATION OF IRAN AND UNITED STATES IN DONALD TRUMP'S SPEECH: A CRITICAL DISCOURSE ANALYSIS. Linguistics and Literature Journal, 1(2), 40-45.

Kapur, V., \& Ghose, S. (2020). Dynamic Learning Spaces in Education. Journal of Applied Learning \& Teaching, 3(2), $18 . \quad$ Retrieved from https://journals.sfu.ca/jalt/index.php/jalt/article/download/277/255/1137

Kuswoyo, H., \& Susardi, S. (2018). Thematic Progression in EFL Students' Academic Writings: A Systemic Functional Grammar Study. Teknosastik, 14(2), 39. https://doi.org/10.33365/ts.v14i2.60

Marume, D. S. B. M., Jubenkanda, R. R., Namusi, C. W., \& Madziyire, N. C. (2016). An analysis of essential elements of the State. International Journal of Engineering Science Invention, 5(3), 24-28. Retrieved from www.ijesi.org

McCombs, M., \& Valenzuela, S. (2007). The Agenda-Setting Theory La teoría Agenda-Setting. Cuadernos de Información, 44-50.

McConnell, E. A., Janulis, P., Gregory, P. I., Truong, R., \& Michelle, B. (2019). Multiple Minority Stress and LGBT Community Resilience among Sexual Minority Men. Psychol Sex Orientat Gend Divers, 5(1), 1-26. https://doi.org/10.1037/sgd0000265.Multiple

Merriam, S. B., \& Tisdel, E. J. (2016). Qualitative Research: A Guide to Design and Implementation. San Fransisco: Jose-Bass.

Morissan, M. (2019). Media Framing on Indonesian Forest Fire in Three ASEAN Affected Neighboring Countries. International Journal of Arts and Social Science, 2(2), 90-101.

Newman, L. L. (2004). Faith, spirituality, and religion: A model for understanding the differences. College Student Affairs Journal, 23(2), 102-110. Retrieved from http://www.eric.ed.gov/ERICWebPortal/recordDetail?accno=EJ956981

Pranoto, B. E., \& Yuwono, U. (2019). Leader's attitude towards terrorism: A critical discourse analysis of Dr. Mahathir Mohamad's diplomatic letters. Cultural Dynamics in a Globalized World, (1991), 65-73. https://doi.org/10.1201/9781315225340-10

Puspita, D., \& Pranoto, B. E. (2021). The attitude of Japanese newspapers in narrating disaster events: Appraisal in critical discourse study. Studies in English Language and Education, 8(2), 796-817.

Radjab, S. (2018). Politik Hukum Penyelesaian Pelanggaran HAM Berat di Era Pemerintahan Jokowi-JK. Jurnal Politik Profetik, 6(2), 151-172.

Rani, M. Z. A. (2010). The History of Hinduism and Islam in Indonesia: a Review on Western Perspective. Makara Human Behavior Studies in Asia, 14(1), 51. https://doi.org/10.7454/mssh.v14i1.572

Reisigl, M. (2012). Discourse-Historical Approach. In J. Paul \& M. Handford (Eds.), The Routledge handbook of discourse analysis (Vol. 50, pp. 50-0712-50-0712). https://doi.org/10.5860/choice.50-0712

Reisigl, M., \& Wodak, R. (2001). Discourse and Discrimination. https://doi.org/10.1177/0957926599010002001 
The Discursive Construction of Indigenous Belief Issue in The Jakarta Post, Suprayogi Suprayogi, Dian Puspita, Sandi Nuansa, Kamelia Sari

Sen, A. (2011). Peace and Democratic Society Edited by Amartya Sen. Retrieved from http://www.oapen.org/search?identifier=633730;keyword=Identity Politics

Sharma, A., Sharma, R., \& Rawat, N. (2018). A Role of Media in Transforming Society. University News: A Weekly Journal of Higher Education, 53(38).

Sumarto, S. (2017). Constitutional protection of religious freedom and belief for indigenous peoples in Indonesia. International Journal of Business, Economics and Law, 12(4), 11-12. Retrieved from https://www.ijbel.com/wp-content/uploads/2017/05/LAW58.pdf

Sunarso, A. (2018). Historiography of Indonesian Islam (Historical Analysis of the Transitional Era of Social and Political System in Java in the 15-16th Century and the Contribution of Javanese Kings in Islamization). IJISH (International Journal of Islamic Studies and Humanities), 1(1), 9-20. https://doi.org/10.26555/ijish.v1i1.129

Tafjord, B. O. (2013). Indigenous religion(s) as An analytical category. Method and Theory in the Study of Religion, 25(3), 221-243. https://doi.org/10.1163/15700682-12341258

Utami, A. D., \& Kurniawan, E. (2017). the Representation of Joko Widodo' S Figure in the Jakarta Post. Indonesian Journal of Applied Linguistics, 6(2), 341-350.

Utami, M. A. (2018). News Media Partiality Concerning LGBT Issues in Indonesia: A Hidden Agenda of The Jakarta Post and Jakarta Globe. Ranah: Jurnal Kajian Bahasa, 7(1), 86. https://doi.org/10.26499/rnh.v7i1.566

Wodak, R. (2011). 2 Between theory, method, and politics: positioning of the approaches to CDA. In Methods of Critical Discourse Analysis (Vol. 1). https://doi.org/10.4135/9780857028020.d4

Wodak, R. (2015). Critical Discourse Analysis, The Discourse-Historical Approach. In K. Tracy (Ed.), The International Encyclopedia of Language and Social Interaction (pp. 63-94). https://doi.org/10.4135/9780857028020.d6

Wodak, R., \& Meyer, M. (2001). Methods of Critical Discourse Analysis Second Edition. London: SAGE Publication.

Yang, H. (2005). The history and legal position of Confucianism in post-independence Indonesia Summary (by editors) Pre-independence historical background. Marburg Journal of Religion, 10(1), 1-8. 